\title{
Self-help Groups as a Means for Development and Welfare: Their Characteristics, Membership and Performance in Kenya
}

\author{
Preston O., Chitere \\ Department of Sociology and Social Work, University of Nairobi, Kenya
}

\begin{abstract}
In Kenya, self-help groups are the main means used by change agencies to work with members of communities on development and welfare matters. However, only a few studies of self-help groups have been completed in the country. This study was based on the self-help approach, the life cycle of self-help groups and the social capital conceptual perspectives. Data presented in this article were collected from 23 self-help groups and their 15 members from nine districts (now, counties) of the country. It was found, among other things, that leaders of the groups were aware of various problems of their communities as well as registration requirements for their groups. Most of the groups had been formed by local leaders with development and welfare concerns as their objectives. About 70 per cent of the groups had performed better compared to the remaining ones. However, among the characteristics of the groups studied, only their formalization in terms of better observance of corporate governance practices and number of activities they carried out explained their better performance compared to the others. Whereas the groups had 15 or more members at the time of registration with the Department of Gender and Social Development, the membership of about a third of them had declined below the required 15 members after their registration. Most of the members were youthful, married and with dependents. All of the members sampled reported making monetary and other contributions, and more than half reported benefitting from their groups. We examined a few groups in detail as case studies and obtained more insights from them on their formation, membership, objectives, activities, performance, achievements and challenges. It was concluded that self-help groups were positively contributing in meeting the development and welfare needs of their members and that there was potential for their efforts to be strengthened.
\end{abstract}

Keywords Self-help Groups, Community, Development, Welfare, Members, Leaders, Activities, ISSN: 2332-6840 (Online) 2332-6832 (Print) Copyright (C) 2018 by authors, all rights reserved. Authors agree that this article remains permanently open access under the terms of the Creative Commons Attribution License 4.0 International License
Performance, Achievements

\section{Introduction}

In Kenya, self-help groups are the main means through which field workers of development and welfare agencies practice the community development approach. This approach emphasizes participation of members of communities and self-help groups in development and welfare activities seeking to improve their lives.

In this study we hold development services to be those that help to build or improve assets of communities such as schools, health facilities, road networks and cattle dips. Development services also build and improve assets of individual members of self-help groups, for example business and farming enterprises such as groceries, poultry and dairy cattle keeping. Welfare services are those which aim at helping members of communities and self-help groups to meet their needs, for instance payment of school fees for their children or settling their hospital bills.

The practice of community development through self-help groups was emphasized in its earlier conceptions by Jackson (1956), the Cambridge Conference on encouragement of initiative in African society ${ }^{1}$, Askwith (1960) and the United Nations (1963). We found that this earlier emphasis on self-help groups was essential when we were preparing Kenya's community development policy. We had, among other things, to collect information on self-help groups to provide a basis for formulation of the policy and legal framework guiding its practice. We used 1 British Colonial office, Encouragement of initiatives in African society.
A Report of the Conference on African Administration, Second session, Cambridge, 1948 
the information gathered through this study to provide insights for the policy development. In this paper, we present the insights emerging from the analysis of self-help groups.

In Kenya, self-help groups are part of the larger self-help movement which Mbithi and Rasmussen (1977) trace to the traditional African society where members of communities formed groups to assist each other in such activities as clearing of bushes, weeding crops, building houses and herding livestock. These traditional self-help efforts were encouraged and promoted by the British colonial administration in the form of betterment or community development work (Chitere, 2012). After Kenya gained her independence in 1963, the self-help work became known as "Harambee" and was considerably expanded following its support by the then Kenyan President, Mzee Jomo Kenyatta and his government policy which emphasized African socialism as a means of people working together for their own betterment (RoK, Sessional paper No. 10, 1965 and RoK Development Plan, 1964-69).

The 21,297 self-help projects implemented in 1965 rose to 27,943 in 1967 and fell to 7,580 in 1972 , to 1,671 in 1977 and to 1,403 in 1981 (Chitere, 1994). These projects focused upon development pertaining to education (e.g., schools), water, health, cattle dips, sanitation (e.g., pit latrines), and housing (e.g., house improvement and construction of teachers' houses). Mbithi and Rasmussen categorized these self-help activities as large (e.g., institutes of technology) versus small scale (e.g., an early childhood development centre) and also as economic (e.g., keeping of dairy cows) versus social (e.g., community hall) projects, and noted that government assistance policy at that time favored economic rather than social projects.

The women's self-help movement was also going on and took the form of clubs during the colonial period and traditional groups during the immediate post-independence period (Chitere, 1988). The clubs carried out handcraft and home improvement activities but declined in importance following the Mau Mau rebellion of the early to mid-1950s. Following independence in 1963, women groups formed along traditional lines emerged in the then central and eastern provinces. The groups danced for political leaders and carried out betterment activities such as buying of corrugated iron sheets and land for their members. This form of the women's movement continued until 1975 when, following the International Women's Year Conference that was held in Mexico that year, the then Department of Social Services (DSS) adopted the term "self-help groups" and it started registering women and mixed gender (both men and women) self-help groups and projects (Chitere, 1988).

Hearsman (1966) indicates that there were 1,600 clubs with 45,000 members at the time she published her paper. In 1972 , there were 2,805 women groups with 126,150 members which increased to 8,225 groups with 326,375 members in 1978 (Monsted, 1978). By mid-1980s, there were an estimated 15,000 groups with 550,000 members (Chitere, 1988). At the time of this study in 2013, there were an estimated 120,000 self-help groups and projects with nearly 1.8 million members (Pers. comm. between author and Head, Community Development Division, DGSD). About half of the groups and projects were active, 25 per cent were semi-active and the remainder was dormant $^{2}$. The reasons for the rapid expansion of the self-help, especially the women's movement include assistance given to the groups by the government and Non-governmental organizations (NGOs), creation of the Women's Bureau in the then Department of Social Services (DSS) and employment of more staff for women's work.

Self-help groups are also known as "community", "people's", "neighborhood", or "interest" groups or organizations. The groups can be seen as individuals in a given situation who mutually agree to work together to attain certain objectives (Wileden, 1970). That is, people form groups to meet one or several of their interests. Groups are the means that individuals use to pursue their goals and aspirations and to lean on each other as they do so. This is because whereas individuals can pursue some aspirations on their own, certain of the aspirations require collective efforts.

Mbithi and Rasmussen (1977) in their discussion of harambee projects viewed groups as helping to meet the economic and social interests of communities. For the self-help groups, the interests are largely those of income generation; and welfare activities. Income generation activities (IGAs) include dairy cattle, goats and sheep, poultry and bee keeping, fish farming, horticulture, catering services at weddings, funerals and related community events, table banking, kiosks and groceries and pottery and basketry. Welfare activities carried out by the groups include provision of sanitation services, vigilantism, and school fees payment for members' children, settling of hospital bills for needy members, and merry-go-round that enable improvement of houses and acquisition of water tanks and other household assets.

Self-help groups also initiate and manage community-wide projects such as day care centers, school classrooms, health facilities, cattle dips, feeder roads and bridges.

The Department of Gender and Social Development (DGSD) was at the time of this study mandated to provide oversight and to register the self-help groups ${ }^{3}$. The

2 The Self-Help Group movement is very fluid. As Kolb (1968) noted, groups form, operate for some time and become dormant as new ones emerge. Whereas they are expected to renew their registration every year, some rarely do so even when active while others become dormant. They are, however, quick to re-activate themselves when opportunity arises, for example a promise of support by some agency. A case in point was the large number of youth and women groups that were formed when the government launched the Uwezo and women development funds for support of their entrepreneurial activities. They also form in large numbers during a year of elections to access support from politicians.

3 Author and senior staff of the DGSD were requested by its Director to 
department's requirements for registration of self-help groups were that the group must: have more than 15 members; open a bank account; must be carrying out some activities (e.g., dairy cattle, poultry and bee keeping, fish farming, tailoring and table banking); clearly outline procedure of its operations; prepare minutes of its last meeting resolving to register with the department; elect officials; prepare a constitution; indicate its physical address; confirm its existence by a local administrator, the chief, along with the necessary documentation completed (e.g., a duly filled form for registration).

The groups were, however, registered by the department administratively since there was no Act of parliament that provided a basis for their registration. In 2015, Kenya's Senate prepared a Bill for registration of the self-help groups. The Bill termed the groups as "self-help associations" and defined them as non-professional entities formed by members of a community from the same socio-economic background with a common problem or situation for the purpose of pooling resources, gathering information and offering mutual support, services or care. Apart from the above requirements of the DGSD, the Bill restricted membership of an association from 5 to 45 persons emphasized the need for a group to have a common socio-economic agenda and to compile a profile of its members.

Lewa (2002) observed that the registration certificate was provided to a group that met these requirements. The registration gave the group identity and served as a basis for assistance by the government and other partners. She studied 20 women groups in the Kenyan coastal town of Mombasa. She found out, among other things that membership of the groups ranged from 10 to 25 and averaged 19 members. The activities of the groups included tailoring, tie and dye, making of mosquito nets, rotating savings and credit, and imparting of skills to their members. Benefits extended by the groups to their members included assistance with the business improvement, payment of school fees for their children, purchase of land and buildings, and home improvement.

In this study, we build on the previous studies and examine in detail the characteristics of the self-help groups, their membership and performance with a view to establishing the extent to which they help their members to realize their development and welfare needs.

\section{Study Objective and Questions}

The main objective of the study was to examine the characteristics of the self-help groups, their performance, and their potential for realizing development and welfare needs of their members.

attend and explain the department's position at the public hearing session of the senate committee, Kenyatta International Conference Centre (KICC), Nairobi, 2015
The study was guided by several research questions: a) To what extent were leaders of the self-help groups aware of problems of their communities and requirements for registration of their groups? b) What were the characteristics of the self-help groups and their individual members? c) What was the extent of performance of the groups in terms of realization of their objectives?; and d) To what extent had the selected case study groups helped members to meet their development and welfare needs?

\section{Rationale}

Kenya's concern about development and welfare of her citizens, and which is equally the concern of self-help groups, goes back to the time of independence (1963) when the government identified illiteracy, disease, ignorance and poverty as the main problems that the country was facing and that needed to be solved (Republic of Kenya, Sessional Paper No.10, 1965). These problems, especially poverty have persisted despite the fact that attempts have been made to address them through national development and welfare policies and programs. In the late 1990s, the number of people falling below the poverty line was 56 per cent although it reduced gradually to 46 per cent in the 2000s. The reduction was a response to the introduction of devolved funds such as the Constituency Development Fund (CDF) and the Local Authority Development Fund (LATIF) which supported various development and welfare projects in communities (Kariuki, 2016).

A major drawback to the development policies and programs was the country's population which was growing at a fast rate from 10.9 million in 1969 to 16 million in 1979, 21.3 million in 1989, 29 million in 1999, 38 million in 2009 and to an estimated 42 million in 2013 (Republic of Kenya, National censuses, 1969, 1979, 1989, 1999 and 2009). In the 1970s and 1980s, the population grew at a rate of 3.8 and then declined to 2.4 per cent per annum by 2013 . This high population growth rate meant increased pressure over scarce resources such as land in rural areas and large movement of people to urban areas in search of employment opportunities. The movement in turn put pressure on urban services leading to rapid growth of slums in cities such as Nairobi.

A major shift in policy occurred in the form of devolution in 2013 following the adoption of the Republic of Kenya Constitution (2010). The constitution, among other things, created 47 county governments with their executives, assemblies, and funding amounting to 15 per cent of the total annual national revenue collection (Chitere and Ngundo, 2013). Space does not permit explanation of this governance system which was launched at the time we were collecting data presented in this article. However, more importantly, the Constitution's Article 36 (1) provides for freedom of association while its articles 53 to 57 provide for affirmative actions for children, persons with disabilities, youth, minorities, marginalized groups 
and older persons. In addition, Kenya Vision 2030's social pillar, among other things, emphasizes equity and elimination of poverty as well as work with women, youth and vulnerable groups. This is the essence of the present study. Self-help groups are one of the main means for bringing together members of these disadvantaged groups, most of whom are poor, and helping them to work together for meeting their development and welfare needs.

\section{Conceptual Framework}

In this study, self-help groups are conceived in terms of: a) self-help approach; b) their life cycle; c) social capital; and d) their types' perspectives.

Self-help approach perspective: Littrell (1980: pages 64-69) noted that one key idea in the theory and practice of community development is the concept of "self-help" which entails the notion or an assumption that people can come and work together to improve their situation. Littrell cited the UN (1959: page 291) definition of community development which emphasizes this notion of self-help:

"The utilization under one single program of approaches and techniques which rely upon local communities as units of action and which attempt to combine outside assistance with organized local self-determination and effort and which correspondingly seek to stimulate local initiative and leadership as the primary instruments of change".

The self-help approach is seen as a process that assumes that people can come together, examine their situation, design plans and implement them assisted by a community development worker who is expected to practice in such a manner that enables people to become increasingly competent to guide their own destiny. Based on this emphasis, Littrell observed that early efforts in community development consisted in assisting people to deal with local concerns such as improving agricultural practices, health programs, roads, school buildings, wells and literacy programs. The programs were usually carried out with the help of a community worker assigned to the area by a sponsoring agency such as the government. The worker provided advice and assisted the community to access support from agencies in the form of simple tools (e.g., shovels, ploughs) and materials (e.g., concrete, fertilizer, seeds, roofing and piping). While providing such support, the worker emphasized the basic idea that the local residents would plan and carry out improvement projects with limited help from outside. Littrell concluded that these earlier approaches were concerned with meeting the basic needs of community. However, in today's complex world, the self-help groups often collaborate with the neighboring communities and groups, contract out project activities and receive support from outside agencies' resources to meet the needs of community development.
Life cycle of group's perspective: Kolb (1968) found self-help groups to emerge, form, operate and decline in what he termed a life cycle comprising of four stages of mobilization, formation, operation and decline.

Mobilization or stimulation stage: At this stage, one or several persons (usually leaders) recognize the need to form a group to solve some problem. The idea for forming the group can also be suggested by a community worker such as the Social Development Officer. This means that the idea of forming a group can come from within (endogenous) or from outside (exogenous).

Formation or rise stage: This is characterized by organization of frequent meetings, discussion about the purpose of the group, selection of a committee of officials, and preparation of constitution and plan of action.

Operation or carrying on stage: This is the longest stage and is characterized by active participation of members of the group in its activities. Problems arise and the group is challenged to deal with them. The group strives to focus and refocus its objectives so as to meet interests of new members that join. The group has to make efforts to continuously satisfy the needs of its members. Where the group is unable to do so and to keep up with the changing circumstances, its life span will be shortened.

Decline stage: This comes faster to some groups than to others. Groups that live longer are those that are able to manage their affairs well or frequently make changes to meet their members' interests. Where decline leads to death of a group, often a new one is formed by some of the members and it starts a life of its own.

Social capital perspective: Kinyanjui (2012) talked of various forms of social capital where blood relationships are referred to as "bonding social capital" while friendship and ethnic based relationships are referred to as "bridging social capital". Individuals related by kinship and friendship ties sometimes make similar decisions on issues and often assist each other during birth, marriage, initiation and funeral rites. Kinyanjui termed the self-help groups vyama (or singular chama in Kiswahili) to describe the new forms of social alliances. These vyama serve as a basis of trust, enlarge interaction between members of communities and permit social action relating to betterment and welfare.

She further articulated that:

"Individuals are working collaboratively in vyama to create alternative forms of economic organization that reduces market transaction costs and share risks. The alliances rely on collective action among individuals who identify their needs, design ways of meeting these needs and decide on how resources are mobilized, pooled and distributed" (page 33).

Kinyanjui noted different types of vyamas - some were largely involved in welfare and social protection while others were involved in market related issues. She added "...by involving themselves in social and market issues, vyama give hope to their members by providing cohesion, 
solidarity, risk sharing, savings and credit...they also serve as...(a means)...for renewing and retooling society through learning. Some vyamas perform multiple tasks" (page 34).

Types of group's perspective: Brager and Specht (1973) viewed groups in terms of their four types including socialization, primary, organization-development and Institutional Relations Organizations (IROs). Socialization and primary groups such as the family and peer groups are mainly concerned with meeting emotional needs of their members and cannot be relied upon to deliver development and welfare services. Organization-development groups are somewhat task oriented while IROs are mature and more development oriented. The implication is that a community worker needs to categorize groups he/she works with into their different types. Given differences in task-orientation of the groups, the worker needs to vary his/her intervention efforts by devoting more time to the IROs than to the other groups. As the worker does this, he/she does not neglect the other groups but helps them to grow gradually and mature to the IRO level.

These perspectives provide a basis for the conceptualization and interpretation of both group- and individual member-level data presented in this article.

\section{Methods Used in the Study}

Data presented in this article were gathered at the beginning of 2013. Nine representative districts (now, counties) of Kakamega, Busia, Kisumu and Kisii to the west; Narok and Baringo in the Rift Valley, Garissa and Embu in eastern; and Mombasa in the coastal area of Kenya were purposively chosen by the author in consultation with the Head, Community Development Division of the then Department of Gender and Social Development (DGSD). Information was gathered from the self-help groups and projects in these districts for purposes of providing insights about the groups during formulation of the community development policy which the author was facilitating. The author visited the districts and was assisted by the then District Social Development Officers (DSDOs) of each district to identify 5 groups that were to provide the information. The groups were those that were: registered by the DGSD, active in their operations and of different types such as unit groups, Community Based Organizations (CBOs) and development committees. However, owing to inadequate time and financial constraints, the researcher after consulting the DSDOs gathered the information from only 2 to 3 of the identified groups from each district giving a total of 23 groups (Table 1).

Of the 23 groups, 15 were primary or unit groups, 4 were CBOs and another 4 were development committees. From each of these 15 unit groups, one leader/member was purposively selected (table 1 and Annex table 1).

Information from each of the groups was gathered through group interviews led by their leaders who were mostly the chairperson, secretary, treasurer and ordinary members. Interview guides were used for gathering the information from both the 23 groups and from the leader/member of each of the 15 unit groups.

Table 1. Sampling of Self-help groups and their members and leaders

\begin{tabular}{|c|c|c|c|c|}
\hline $\begin{array}{c}\text { Former } \\
\text { Province }\end{array}$ & $\begin{array}{c}\text { Former District } \\
\text { (Now, County) }\end{array}$ & $\begin{array}{c}\text { Primary/Unit Self-Help } \\
\text { Groups Sampled }\end{array}$ & $\begin{array}{c}\text { CBOs/Development } \\
\text { Committees Sampled }\end{array}$ & $\begin{array}{c}\text { Members/leaders of Unit } \\
\text { Groups Sampled }\end{array}$ \\
\hline Western & Kakamega & 1 & 2 & 2 \\
\hline & Busia & 1 & 1 & 1 \\
\hline Nyanza & Kisii & 1 & 1 & 2 \\
\hline Rift Valley & Baringo & 2 & 1 & 2 \\
\hline & Narok & 2 & 1 & 3 \\
\hline Coast & Mombasa & 4 & 1 & 2 \\
\hline Eastern & Embu & 1 & - & 3 \\
\hline & Garissa & 3 & 8 & 15 \\
\hline Total & & 15 & & 1 \\
\hline
\end{tabular}


Variables of the study

Four variables including awareness among the leaders, characteristics, membership, and performance of the self-help groups were measured in the study (Table 2).

Table 2. Variables of the study

\begin{tabular}{|l|l|}
\hline \multicolumn{1}{|c|}{ Variable } & \multicolumn{1}{c|}{ Indicators } \\
\hline $\begin{array}{l}\text { Awareness among } \\
\text { the leaders }\end{array}$ & $\begin{array}{l}\text { Extent to which leaders were informed } \\
\text { about problems of their communities } \\
\text { Registration requirements for their } \\
\text { groups }\end{array}$ \\
\hline - & $\begin{array}{l}\text { Sources of ideas for formation of the } \\
\text { groups } \\
\text { Age in years } \\
\text { Characteristics } \\
\text { the self-help groups } \\
\text { Types whether unit group, CBO or } \\
\text { development committee }\end{array}$ \\
Objectives \\
Activities whether development, \\
welfare or both
\end{tabular}

In the forthcoming section, we present data on these variables related to the 23 groups as well as the perceptions of the 15 leaders/members followed by case studies of a few of the sampled groups.

\section{Results of the Study}

\section{Awareness of Leaders of the Groups about Problems and Registration Requirements}

The first question that this study set out to answer was about the extent to which the self-help group leaders were aware of the problems of their communities and requirements for registration of their groups. It was likely that self-help groups whose leaders were aware of the problems would formulate realistic objectives that would benefit their members.

When we asked the leaders to mention the problems of their communities that their groups sought to solve, they responded as shown in Table 3. Poverty with associated low income was the most mentioned problem by 16.4 per cent followed by low education, illiteracy and ignorance (14.9\%), poor farming (10.5\%), lack of entrepreneurship, business education and Income Generating Activities (IGAs) $(7.5 \%)$, and lack of health centers and diseases including HIV/AIDs (7.5\%). Other problems such as lack of water and negative attitudes toward Persons with Disabilities (PWDs) were each mentioned by a small percentage of the leaders of the groups.

Table 3. Problems of the communities identified by the group leaders

\begin{tabular}{|c|c|c|}
\hline Responses & $\begin{array}{c}\text { Number of } \\
\text { Groups }\end{array}$ & $\begin{array}{l}\text { Per } \\
\text { cent }\end{array}$ \\
\hline Poverty-lack of/low income & 11 & 16.4 \\
\hline Low education-illiteracy, ignorance & 10 & 14.9 \\
\hline $\begin{array}{l}\text { Poor farming/food shortages owing to } \\
\text { poor soils, drought, fear of credit }\end{array}$ & 7 & 10.5 \\
\hline $\begin{array}{l}\text { Lack of health centers, diseases and } \\
\text { HIV/AIDs }\end{array}$ & 5 & 7.5 \\
\hline $\begin{array}{c}\text { Lack of entrepreneurial attitude, business } \\
\text { education and IGAs }\end{array}$ & 5 & 7.5 \\
\hline Lack of water or its wastage & 4 & 6.4 \\
\hline Negative attitudes/stigma toward PWDs & 4 & 6.4 \\
\hline Theft/house breakages/insecurity & 3 & 4.5 \\
\hline $\begin{array}{c}\text { Adherence to local culture and poor use } \\
\text { of resources }\end{array}$ & 3 & 4.5 \\
\hline Poor livestock husbandry and diseases & 2 & 3.0 \\
\hline $\begin{array}{l}\text { Neglect of PWDs in regard to } \\
\text { opportunities }\end{array}$ & 2 & 3.0 \\
\hline $\begin{array}{c}\text { Transport problems, especially during } \\
\text { rainy season }\end{array}$ & 2 & 3.0 \\
\hline $\begin{array}{l}\text { Lack of employment/skills among the } \\
\text { youth }\end{array}$ & 2 & 3.0 \\
\hline Middlemen/ price fluctuations & 2 & 3.0 \\
\hline $\begin{array}{l}\text { Lack of care and support of orphans and } \\
\text { vulnerable children (OVCs) }\end{array}$ & 1 & 1.5 \\
\hline Lack of office & 1 & 1.5 \\
\hline Drugs/subsistence abuse & 1 & 1.5 \\
\hline Absenteeism from group meetings & 1 & 1.5 \\
\hline $\begin{array}{l}\text { Marauding wild animals which destroy } \\
\text { crops }\end{array}$ & 1 & 1.5 \\
\hline Total & 67 & 100 \\
\hline
\end{tabular}

*Some leaders mentioned more than one problem

Apart from awareness of the above problems, the study also sought to find out to what extent leaders of the self-help groups were aware of the requirements for registration of their groups. It was likely that leaders who were aware would ensure not only registration but also effective operations of their groups.

When the leaders were asked what the requirements of the DGSD for registration of their groups were, they responded as shown in table 4. The responses were: minutes of previous meeting of the group which were most frequently mentioned $(21.0 \%)$ followed by the group's constitution (19.4\%), having registration fee $(19.4 \%)$, having at least 15 members $(12.9 \%)$ and having chosen office bearers $(9.7 \%)$. Other responses mentioned by a few group leaders pertained to undertaking some development or welfare activities and to renewal of registration every year. 
Table 4. Requirements for registration as reported by the group leaders

\begin{tabular}{|c|c|c|}
\hline Requirements/Conditions & Frequency* $^{*}$ & Per cent \\
\hline $\begin{array}{c}\text { Must have minutes of their meeting } \\
\text { resolving that group be registered }\end{array}$ & 13 & 21.0 \\
\hline $\begin{array}{c}\text { Must have prepared constitution with } \\
\text { rules and regulations }\end{array}$ & 12 & 19.4 \\
\hline $\begin{array}{c}\text { Must have registration fee of Kshs } \\
1,000 \text { (US\$ 10) }\end{array}$ & 12 & 19.4 \\
\hline Must have a list of 15 or more members & 8 & 12.9 \\
\hline $\begin{array}{c}\text { Must have chosen office } \\
\text { bearers/management } \\
\text { team chairperson, treasurer and } \\
\text { secretary }\end{array}$ & 6 & 9.7 \\
\hline $\begin{array}{c}\text { Must have started carrying out some } \\
\text { activities }\end{array}$ & 3 & 4.8 \\
\hline $\begin{array}{c}\text { Must renew registration annually by } \\
\text { submitting copies of progress reports } \\
\text { and paying renewal fee of Kshs 500 } \\
\text { (US\$5) }\end{array}$ & 4 & 6.5 \\
\hline $\begin{array}{c}\text { Must have a recommendation letter } \\
\text { from Assistant Social Development } \\
\text { Officer (ASDO)/chief }\end{array}$ & 1 & 1.6 \\
\hline $\begin{array}{c}\text { Must show that members had been } \\
\text { making monthly monetary } \\
\text { contributions }\end{array}$ & 1 & 1.6 \\
\hline Must have name of the group & 1 & 100 \\
\hline Must fill registration form & 62 & 1.6 \\
\hline Total & 1 & 1.6 \\
\hline
\end{tabular}

*Some of the groups mentioned more than one requirement.

The above responses show that most leaders were aware of the problems faced by the communities and the registration requirements for the self-help groups.

\section{Characteristics of the Self-help Groups}

A second research question was about the characteristics of the self-help groups. The characteristics included the formation of group, the age of group, objectives, activities, the type of group, the form of support received from agencies, and membership.

Sources of ideas for formation of the self-help groups: It was our view that groups whose idea for their formation came from within the community were likely to have higher sense of ownership, to perform better on various activities, and to achieve their objectives compared to the groups whose formation was driven by external sources. When asked about the source of the idea for the formation of their groups, leaders of 87 per cent of the groups reported that ideas came from within; that is, from their current leaders and founders while those of the remaining groups reported that ideas came from outsiders mainly the then DGSD staff or chiefs of their areas. The fact that the idea for formation of most of the groups came from within the community may have increased the leaders' sense of ownership of the groups and presumably led to their better performance.

When we cross-tabulated sources of ideas for formation of groups to their performance, we found no marked association between the two variables implying that source of ideas for formation of the groups did not influence their performance (Table 11).

Age of the Groups: Our view was that older groups had more experience in their operations and were likely to perform better and achieve their objectives than the newer ones. When asked the year they formed their groups, leaders of 21.7 per cent noted that their groups had been formed more than ten (10) years earlier in 1980s and 1990s, 47.8 per cent said that their groups were formed between 2000 to $2005,26.1$ per cent reported forming their groups between 2006 to 2010 while leaders of 4.4 per cent could not recollect when their groups were formed. The oldest group had been formed in 1987 and the newest in 2010 . This implied that most (nearly 70\%) of the groups were old having been formed more than 6 years ago.

When we cross-tabulated age of the groups with their performance, we found no marked association between the two variables implying that newer groups performed equally as the older ones (Table 11).

Types of groups: In Kenya, the two main types of self-help groups are, (a) unit group which is a single primary group and (b) a CBO which is a secondary or an umbrella organization formed by two or more unit groups. A third type are the development committee which are also secondary and umbrella organizations formed by representatives of the above groups with staff of the DGSD serving in ex-officio capacity. It was likely that unit groups which usually have a few individual members who are intimate and frequently interact performed better than CBOs and committees where intimacy and frequency of interaction of the members were reverse. Of the 23 self-help groups sampled, 26.1 per cent were women groups, 21.7 per cent were mixed with both women and men members, 17.4 per cent were for Persons with Disabilities (PWDs), 17.4 per cent were Community-Based Organizations (CBOs), 8.7 per cent were Village Development Committees (VDC)/projects and the remainder $(8.7 \%)$ were the District Community Development Committee (DCDC) and the District Social Protection Committee (DSPC). The VDCs were started on the initiative of development partners in collaboration with the DGSD while the DCDC and the DSPC were both initiated and operated by representatives of self-help groups with guidance from the DGSD.

We cross-tabulated types of groups and their performance and found that there was no significant association between the two variables indicating that various types of unit groups performed more-or-less at the same level as the CBOs and the committees (Table 11).

The DGSD differentiates a single or unit group comprising leaders and individual members and a $\mathrm{CBO}$ as an umbrella group formed by two or more single or unit groups (RoK, DGSD, Report, 2012). The case of the VDC also shows that donor funded projects might work outside the framework of existing groups by requiring the DGSD to mobilize communities and work with them through their Village Development Committees/ projects (VDCs). A case in point was the Businda VDC in Busia area of Kenya. 
Self-help groups including CBOs choose their representatives who constitute the District (now, county) Social Development Committee (DCDC). However, when new programs such as social protection are launched, stakeholder groups are mobilized by the DGSD and assisted to choose their representatives to the newly formed district committee. A case in point was the District Social Protection Committee (DSPC) which was sampled in this study.

The manner in which groups are categorized, especially into unit groups and CBOs is not consistent with Brager and Specht's categories of socialization, primary, organization-development and IROs. Similarly, the measures of performance we have used do not show which of the unit groups and CBOs are more task-oriented and hence more mature than the others.

Objectives of the groups: Since all the groups had objectives, we held that those which had single were likely to perform better than those which had multiple objectives. Of the objectives of the groups reported by their leaders, uplifting of members' welfare through business, IGAs and other forms of support was the most mentioned (22.2\%), followed by improving education and health (14.8\%), overcoming hunger and poverty by improving agriculture (11.1\%), promoting equitable and sustainable development and protecting the environment $(11.1 \%)$ and promoting and lobbying for interests of the disabled (11.1\%) (Table5). A number of other objectives such as to mobilize, sensitize and train PWDs for HIV/AIDs awareness and to raise level of education of Orphans and Vulnerable Children (OVCs) were each reported by a small percentage of the groups.

Table 5. Objectives of the Self-help Groups

\begin{tabular}{|c|c|c|}
\hline Objectives* & $\begin{array}{c}\text { Number of } \\
\text { Groups }\end{array}$ & $\begin{array}{l}\text { Per } \\
\text { cent }\end{array}$ \\
\hline $\begin{array}{c}\text { Uplift welfare of members through } \\
\text { education, business, IGAs and support } \\
\text { when in need }\end{array}$ & 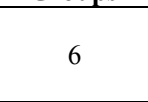 & 22.1 \\
\hline $\begin{array}{l}\text { Improve/provide education, health, } \\
\text { bursaries }\end{array}$ & 4 & 14.8 \\
\hline $\begin{array}{l}\text { Overcome poverty including hunger (njaa) } \\
\text { by improving agriculture }\end{array}$ & 3 & 11.1 \\
\hline $\begin{array}{c}\text { Promote equitable and sustainable } \\
\text { development and protection of } \\
\text { environment }\end{array}$ & 3 & 11.1 \\
\hline Promote/lobby interests/rights of PWDs & 3 & 11.1 \\
\hline $\begin{array}{l}\text { Help each other when in problems such as } \\
\text { funerals and school fees }\end{array}$ & 2 & 7.4 \\
\hline $\begin{array}{c}\text { Mobilize, sensitize and train PWDs on } \\
\text { HIV/AIDs awareness }\end{array}$ & 1 & 3.7 \\
\hline Raise level of education of OVCs & 1 & 3.7 \\
\hline $\begin{array}{l}\text { Establish unity among neighbours, friends } \\
\text { and business persons }\end{array}$ & 1 & 3.7 \\
\hline $\begin{array}{c}\text { Harness and nurture Muslim youth } \\
\text { potential, strengthen their organizational } \\
\text { capacities }\end{array}$ & 1 & 3.7 \\
\hline $\begin{array}{l}\text { Build a workshop for PWDs for welding, } \\
\text { carpentry, tailoring, metal work and rope } \\
\text { making }\end{array}$ & 1 & 3.7 \\
\hline Enhance free livestock trade & 1 & 3.7 \\
\hline Total & 27 & 100 \\
\hline
\end{tabular}

*Some groups had more than one objective
We cross-tabulated the objectives of the groups and their performance and found no marked association between them. This in effect implied that groups which had single objectives performed just as well as those which had multiple objectives.

Support provided to the groups by development agencies: It was likely that groups which had been supported by development agencies were performing better than those in the reverse situation. When we asked the leaders whether their groups had been assisted by development agencies with monetary grants, training or in other ways, they responded as shown in Table 6.

Table 6. Support provided to the groups by development agencies

\begin{tabular}{|c|c|c|}
\hline \multirow{2}{*}{$\begin{array}{c}\text { Development } \\
\text { Agency }\end{array}$} & \multicolumn{2}{|c|}{ Received Support } \\
\cline { 2 - 3 } $\begin{array}{c}\text { Department of Social } \\
\text { Development }\end{array}$ & 13 & Per cent \\
\hline Other agencies & 9 & 52.0 \\
\hline $\begin{array}{c}\text { Ministry of } \\
\text { Agriculture }\end{array}$ & 2 & 36.0 \\
\hline $\begin{array}{c}\text { Ministry of Health's } \\
\text { Afya II program }\end{array}$ & 1 & 8.0 \\
\hline Total & 25 & 4.0 \\
\hline
\end{tabular}

*Some groups had received support from more than one agency

Whereas 13 per cent of the groups had not received financial assistance, a number had received the assistance from several sources. A case in point was Enaitoti Biashara CBO in Narok which had received Ksh. 20,000 (US\$ 200) from Christian Partners, Ksh. 355,000 (US\$ 3,350) from Action Aid Kenya, Ksh. 10, 065 (US\$ 100.65) from World Concern, Ksh.200,000 (US\$ 2,000) from National Aids Coordination Council (NACC) and Ksh.175,000 (US\$ 1,750) from the Ministry of Health's (MoH) Afya II program.

Apart from the main facilitating agency's (DGSD) grants to the groups, other agencies that supported the groups included, Maendeleo Ya Wanawake (Progress for women) Organization, Clarion, World Concern, World Sires, Womankind Kenya, Ministry of Agriculture (MoA) and $\mathrm{MoH}$. The DGSD provided grants to self-help groups and was reported as having assisted 52 per cent of them. The financial assistance provided by the department ranged from Ksh. 14,500 (US\$ 145) to Ksh. 50,000 (US\$ 500). Amounts given by the other agencies, mainly Non-Governmental organizations (NGOs), were much larger and ranged from Ksh. 70,000(US\$ 700) to Ksh.500,000 (US\$ 5,000).

Number of activities carried out by the self-help groups: Since each of the groups carried out several activities, we assumed that the groups that carried out fewer activities (1-2) owing to focused and concentrated use of their resources would do better than the ones which undertook multiple activities. It was likely that groups carrying on multiple activities met interests of more of their 
members than those in reverse situation. The 21 self-help groups (excluding the DSDC and the DSPC) were carrying out various types of betterment and welfare activities. Table 7 shows that farming was reported by several groups $(19.6 \%)$ followed by merry-go-round $(9.8 \%)$, business (9.8\%), health including Bamako Initiative (1987) $(9.8 \%)$, Orphans and Vulnerable Children's (OVC) education and care $(9.8 \%)$ and water projects $(7.8 \%)$. Other activities such as table banking/IGAs, awareness raising and advocacy, capacity building and training, and environment/tree nursery were reported by a small percentage of the groups.

Table 7. Activities carried out by the self-help groups

\begin{tabular}{|c|c|c|}
\hline Activities & $\begin{array}{c}\text { Number of } \\
\text { Groups* }\end{array}$ & $\begin{array}{l}\text { Per } \\
\text { cen }\end{array}$ \\
\hline $\begin{array}{l}\text { Farming/horticulture including fish } \\
\text { pond, poultry, water pumps and } \\
\text { beekeeping }\end{array}$ & 10 & 19.6 \\
\hline Merry-go-round & 5 & 9.8 \\
\hline $\begin{array}{l}\text { Business - retail shop, furniture } \\
\text { making, dress making, selling second } \\
\text { hand clothes, and rental house }\end{array}$ & 5 & 9.8 \\
\hline $\begin{array}{c}\text { Health-Bamako initiative*, } \\
\text { community health care, HIV/AIDs }\end{array}$ & 5 & 9.8 \\
\hline OVC education, care and support & 5 & 9.8 \\
\hline $\begin{array}{l}\text { Water projects-shallow wells, } \\
\text { rehabilitation of dam and selling water }\end{array}$ & 4 & 7.8 \\
\hline Capacity building/training & 3 & 5.9 \\
\hline $\begin{array}{l}\text { Environmental conservation including } \\
\text { tree nursery }\end{array}$ & 3 & 5.9 \\
\hline $\begin{array}{l}\text { Education-Early Childhood } \\
\text { Development, school fees }\end{array}$ & 2 & 3.9 \\
\hline Table banking/IGA & 2 & 3.9 \\
\hline Awareness raising and advocacy & 2 & 3.9 \\
\hline Revolving Loan Fund & 1 & 2.0 \\
\hline Beads making & 1 & 2.0 \\
\hline $\begin{array}{c}\text { Lobby for interests of PWDs and fight } \\
\text { stigma }\end{array}$ & 1 & 2.0 \\
\hline Literacy classes & 1 & 2.0 \\
\hline Livestock trade & 1 & 2.0 \\
\hline Total & 51 & 100 \\
\hline
\end{tabular}

*Some groups were carrying out more than one activity

We cross-tabulated the number of activities that the groups carried out with their performance (Table 11).The table shows that there was marked association between the two variables. Contrary to our expectation, groups which had multiple activities presumably owing to their being able to meet interests of more members tended to perform better than those with few activities.

Level of formalization of the self-help groups: Wileden (1970) categorized community groups into formal and informal ones. Informal groups were those whose members held meetings but had not chosen their officials or established their operation procedures. He noted further that such informal groups could be seen as action groups which emerged to do a job and broke up as soon as the job was done - that is, they were very temporary and broke up or became inactive or dormant as soon as the need which led to their emergence was met. The groups included workgroups, beer parties and some-merry go-rounds. In Kenya, such informal groups are not registered by the DGSD. Formal groups are those that have chosen officials, hold meetings regularly and have clear goals(s)/objectives. In Kenya formal groups are those which have been registered by the DGSD. They include women's and other types of self-help groups and CBOs.

Whereas groups may be formal, their level of formalization often differs with some being more formal than others. We measured the extent of formalization of the groups in terms of their adoption of the corporate governance practices (e.g., holding of regular elections and meetings, having prepared a constitution). When we asked the leaders of the groups about the corporate governance practices their groups had observed, they responded as shown in Table 8.

Table 8. Level of formalization of the self-help groups

\begin{tabular}{|c|c|c|}
\hline Practices & Yes-Frequency* & $\begin{array}{c}\text { Per } \\
\text { cent }\end{array}$ \\
\hline Elections held regularly & 20 & 13.1 \\
\hline Meetings held regularly & 22 & 14.4 \\
\hline Constitution prepared & 21 & 13.7 \\
\hline Keeping of records done & 21 & 13.7 \\
\hline $\begin{array}{c}\text { Decisions made collectively } \\
\text { Group not supported or allied to } \\
\text { politicians/chiefs }\end{array}$ & 16 & 10.5 \\
\hline $\begin{array}{c}\text { Group represented in community } \\
\text { committees }\end{array}$ & 16 & 13.1 \\
\hline $\begin{array}{c}\text { Gender/youth and other groups } \\
\text { represented }\end{array}$ & 18 & 11.8 \\
\hline Total & 153 & 100 \\
\hline
\end{tabular}

*Nearly all groups reported more than one good corporate governance practice

The table shows that most groups were carrying out governance practices as expected. The groups had prepared their constitutions, kept records of their activities, carried out elections and operated neutrally without seeking support from politicians and chiefs. Decision making in some groups was not collectively done as it was left to the executive committee, chairperson or treasurer. A leader of one group said... "Involvement of politicians will divide members of the group..." A leader of another group dealing with environmental matters said... "Politicians don't understand environmental issues".

When we cross-tabulated the level of formalization of the groups and their performance, we found significant association between the two variables (Table 11). This implied that formal groups which observed corporate governance practices tended to perform better than those which did not fully do so.

Membership in the self-help groups: One of the 
DGSD's requirements was that to qualify for registration, single groups needed to have at least 15 members. Of the 15 single- mixed-, women- and PWD groups sampled, membership of a third of them fell below 14, 20 per cent fell between 15 to $19,26.7$ per cent fell between 20 to 29 while the remaining 20 per cent had more than 30 members. The range was from 11 members at the lowest to 49 at the highest. This implied that whereas the groups met requirement of 15 members at the time of registration, membership of some of them had thereafter declined below this threshold.

Fifteen (15) individual members of the groups were sampled (one from each of the individual unit groups). We asked them questions about their characteristics, activities their groups were carrying out, their reasons for joining the groups, their contributions, and the benefits they had derived from the groups.

The characteristics were: their age, gender, and marital status, number of dependents and level of formal schooling. We had the view that these characteristics influenced performance of the groups and achievement of their goals. Of the 15 members sampled, 13.4 per cent were youth, below 29 years, 20 per cent were between the ages of range of 30-39 years, 33.3 per cent were between the age range of 40-49 years and an equal number were above 50 years. Seventy three (73) per cent were women and the remainder was men. In terms of marital status, 93.3 per cent were married and the remainder was either single or widowed. When asked about the number of dependents (e.g., children, aged parents and other relatives), 13.3 per cent had none, 20 per cent had less than four, 46.7 per cent had 5-9 and the remainder had more than 10 dependents. In terms of their level of formal schooling, a third had primary education (1-8 years), 60 per cent had secondary education (9-12 years) and the remainder had completed post-secondary education.

Being members of their self-help groups, we sought to know from them what activities their groups were undertaking with a view to confirming whether they were development or welfare in nature. Farming of crops, livestock and fish were the most mentioned activities by $31.6 \%$, followed by merry-go-round/table banking (17.2\%), business/livestock trade $(17.2 \%)$, health, education and water (17.2\%), revolving loan/savings (10.4\%), and mutual aid of each other and vocational training each mentioned by $3.5 \%$ of the respondents.

Given that self-help groups are interest organizations, we sought to know the reasons that had led the members to join them. The members mentioned that they joined the groups to get employment and income (20\%), to participate in merry-go-round (13.3\%), to get help as widow/student $(13.3 \%)$, to pool resources with others $(6.7 \%)$, to get exposure to HIV/AIDs education (6.7\%), to be assisted as youth $(6.7 \%)$, to learn more about development $(6.7 \%)$, to hear about the group (6.7\%)and to join $\mathrm{CBO}$ through its unit group (6.7\%). Most of the reasons given by the respondents were about their development and welfare concerns.

One requirement of membership was that a member had to make contributions to his/her group in the form of money, labour, materials and decision making. All respondents reported having paid membership fee when joining their groups which varied from Ksh. 50 (US\$ 0.50) to Ksh. 200 (US\$2). All respondents also reported making contributions to their groups usually on a monthly basis although a few groups required more frequent contributions as on a weekly basis. The contributions ranged from as little as Ksh.20 to Ksh. 400 (US\$ 4) with most groups requiring Kshs 50 (US\$ 0.50 ) to Kshs 100 (US\$1) per month.

Finally, given that members joined groups to meet one or several of their interests, we sought to know what benefits they had derived from their groups (table 9). Visits by the DGSD and other agency staff were the most commonly reported benefits, followed by training in business and farming, and business support.

Table 9. Benefits obtained by the respondents from their groups

\begin{tabular}{|c|c|c|}
\hline Type of benefit & Frequency* $^{*}$ & $\mathbf{\%}$ \\
\hline $\begin{array}{c}\text { Visits by government and NGO staff } \\
\text { such as District Social Development } \\
\text { Officers (DSDOs) }\end{array}$ & 10 & 16.9 \\
\hline $\begin{array}{c}\text { Training in business/farming, water, } \\
\text { energy and hairdressing skills }\end{array}$ & 9 & 15.3 \\
\hline $\begin{array}{c}\text { Business support in the form of } \\
\text { grants and loans }\end{array}$ & 8 & 13.6 \\
\hline $\begin{array}{c}\text { Network with other groups and } \\
\text { agencies }\end{array}$ & 7 & 11.9 \\
\hline $\begin{array}{c}\text { Exchange visits, education trips, } \\
\text { agricultural shows }\end{array}$ & 6 & 10.2 \\
\hline $\begin{array}{c}\text { Farming support in the form of } \\
\text { poultry, fish and goats }\end{array}$ & 6 & 10.2 \\
\hline Payments by groups & 3 & 5.1 \\
\hline $\begin{array}{c}\text { Revolving loan, merry-go-round, } \\
\text { savings }\end{array}$ & 2 & 5.1 \\
\hline School fees & 2 & 3.4 \\
\hline Sharing of ideas & 1 & 1.7 \\
\hline Singing at a function & 1 & 1.7 \\
\hline Facilitating training & 59 & 100 \\
\hline Bamako initiative & Total & 3 \\
\hline
\end{tabular}

*Most of the leaders/members mentioned more than one benefit

When we asked the respondents to indicate the ways in which the groups had improved their lives, they responded that the groups had provided them revolving loans and supported their children, OVCs and businesses (40\%), and assisted them in their farming $(25 \%)$. Other responses were that the groups had imparted them knowledge about rights of women, children and PWDs (10\%), assisted them financially $(10 \%)$, and helped them access water and Bamako and other help (5\%). 


\section{Performance of the Self-help Groups}

We measured performance in terms of the benefits realized for the members (see Table 10).

Table 10. Benefits reported by the groups

\begin{tabular}{|c|c|c|}
\hline Performance & $\begin{array}{c}\text { Number of } \\
\text { Groups }\end{array}$ & Per cent \\
\hline $\begin{array}{c}\text { Better farming - poultry, goats, sheep } \\
\text { and crops }\end{array}$ & 4 & 20.0 \\
\hline $\begin{array}{c}\text { Helped members with school fees and } \\
\text { to solve other problems }\end{array}$ & 3 & 15.0 \\
\hline $\begin{array}{c}\text { Bought commercial plot for business } \\
\text { and training }\end{array}$ & 2 & 10.0 \\
\hline Paid dividends to members & 2 & 10.0 \\
\hline Started fish pond and selling of fish & 1 & 5.0 \\
\hline Training of members & 1 & 5.0 \\
\hline Improved health facilities and services & 1 & 5.0 \\
\hline Improved income & 1 & 5.0 \\
\hline Advocacy for their rights & 1 & 5.0 \\
\hline Aided OVCs & 1 & 5.0 \\
\hline $\begin{array}{c}\text { Upgraded livestock through Artificial } \\
\text { Insemination }\end{array}$ & 1 & 5.0 \\
\hline Established tree nursery & 1 & 5.0 \\
\hline $\begin{array}{c}\text { Exposed women to information and } \\
\text { made them pro-active }\end{array}$ & 1 & 5.0 \\
\hline Total & 20 & 100 \\
\hline
\end{tabular}

Whereas a few groups reported extending two or more benefits to their members, 21.7 per cent of them had not done so.

\section{Relationships between Performance and the Other Variables of Study}

We cross-tabulated the characteristics of the groups with their performance and came up with table 11 . We took a proportion difference of more than 0.40 as indicating significant association between the cross-tabulated variables. The table shows that out of the various characteristics of the groups studied, only level of formalization and number of activities carried out by the groups was related to their better performance with proportion differences of 0.42 and 0.52 , respectively. That is, groups that were more formal and those that were carrying out multiple activities tended to perform better than those in the reverse situations. There was no significant association between performance and the other characteristics such as age of the groups, their types and objectives which implied that differences in performance of the groups could not be explained on the basis of these characteristics.

Table 11. Relationships between characteristics of the SHGs and their performance

\begin{tabular}{|c|c|c|c|c|c|}
\hline \multirow{2}{*}{$\begin{array}{l}\text { Characteristics of the } \\
\text { Self-Help Groups }\end{array}$} & \multirow[t]{2}{*}{$\begin{array}{c}\text { Categories of the Characteristics } \\
\text { of the Self Help Groups }\end{array}$} & \multicolumn{2}{|c|}{ Performance of the SHGs } & \multirow[t]{2}{*}{ Total } & \multirow[t]{2}{*}{ (Base) } \\
\hline & & Yes, Some & None & & \\
\hline \multirow{3}{*}{ Leaders' Awareness } & Aware & 0.61 & 0.39 & 1.0 & $(18)$ \\
\hline & Somewhat aware & 1.0 & 0 & 1.0 & $(5)$ \\
\hline & Difference & \multicolumn{2}{|c|}{$0.39 *$} & & \\
\hline \multirow{3}{*}{$\begin{array}{l}\text { Source of idea for } \\
\text { formation of SHG }\end{array}$} & From within community & 0.65 & 0.35 & 1.0 & $(20)$ \\
\hline & From outside & 1.0 & 0 & 1.0 & (3) \\
\hline & Difference & \multicolumn{2}{|c|}{$0.35 *$} & & \\
\hline \multirow{3}{*}{ Age of the SHGs } & Above 7 years & 0.65 & 0.35 & 1.0 & $(17)$ \\
\hline & Below 6 years & 0.80 & 0.20 & 1.0 & $(5)$ \\
\hline & Difference & \multicolumn{2}{|c|}{0.15} & & \\
\hline \multirow{3}{*}{$\begin{array}{c}\text { Financial support for } \\
\text { the SHGs }\end{array}$} & Yes, supported & 0.64 & 0.36 & 1.0 & (14) \\
\hline & No support & 0.78 & 0.22 & 1.0 & (9) \\
\hline & Difference & \multicolumn{2}{|c|}{$0.14^{*}$} & & \\
\hline \multirow{3}{*}{ Objectives of the SHGs } & Single & 0.58 & 0.42 & 1.0 & $(12)$ \\
\hline & Multiple & 0.82 & 0.18 & 1.0 & $(11)$ \\
\hline & Difference & \multicolumn{2}{|c|}{$0.24 *$} & & \\
\hline \multirow{3}{*}{$\begin{array}{l}\text { Number of activities } \\
\text { carried out by the SHGs }\end{array}$} & Few $(1-2)$ & 0.44 & 0.56 & 1.0 & (9) \\
\hline & Multiple (>3) & 0.86 & 0.14 & 1.0 & $(14)$ \\
\hline & Difference & \multicolumn{2}{|c|}{$0.42 *$} & & \\
\hline \multirow{3}{*}{$\begin{array}{l}\text { Level of formalization } \\
\text { of group }\end{array}$} & $\begin{array}{l}\text { Yes, better observed governance } \\
\text { practices }\end{array}$ & 0.92 & 0.08 & 1.0 & (13) \\
\hline & $\begin{array}{c}\text { Yes, some observation of } \\
\text { governance practices }\end{array}$ & 0.40 & 0.60 & 1.0 & $(10)$ \\
\hline & Difference & \multicolumn{2}{|c|}{$0.52 *$} & & \\
\hline \multirow{3}{*}{$\begin{array}{l}\text { Types of self-help } \\
\text { groups }\end{array}$} & Unit Group & 0.67 & 0.33 & 1.0 & $(15)$ \\
\hline & CBOs/Committees & 0.75 & 0.25 & 1.0 & $(10)$ \\
\hline & Difference & \multicolumn{2}{|c|}{$0.08^{*}$} & & \\
\hline
\end{tabular}

*We treated differences in proportions of 0.40 and above as showing significant association between the above characteristics and performance of the groups. 


\section{Case Studies of Selected Self-help Groups}

The study, among other things, sought to shed more light on the characteristics and performance of the self-help groups and the extent to which they were meeting the development and welfare needs of their members. To be able to do so, a few of the self-help groups, a unit group, a Community-Based Organization (CBO), a village development committee (VDC) and a District Social Development Committee (DSDC) were chosen as the case studies. The information on each of them was provided by its leaders on the year it was started, its membership, its objectives and activities, and its achievements and challenges. Space does not permit detailed presentation of information collected on each of them.

\section{Kabarnet Physically Challenged Youth Group}

This group was started in 2007 with the objectives to empower the physically challenged; and to start businesses of tree nursery, beehives and merry-go-round. At the time of data collection, the group had 34 members (22 men and 12 women). The major problems identified by the leaders pertained to the neglect of the disabled in allocations of the Constituency Development Fund (CDF), stigma which persisted when they were seeking opportunities, lack of know-how and skills in business, low levels of education, and discrimination in employment. One of the leaders said... "One of our members, owing to stigma and neglect by brothers... died of njaa (hunger) last month".

Six leaders of the group attended a seminar organized by the Department of Gender and Social Development that discussed the United Nation's Action Plan on disabilities and the Kenyan Parliament Act of 2003. The department gave welding and knitting machines to the group. Members of the group met monthly to discuss its affairs. The group's main achievement was the tree nursery that it was operating. One leader said “...the group had brought members together...they were able to share ideas... were known to the District Commissioner (DC), the Social Development Officer (SDO), mayor and Member of Parliament...stigma was reducing..."The group's leaders reported that they worked directly with the DC and SDO and avoided involving themselves with politicians.

\section{Mosocho Livestock SHG, Kisii County}

The CBO was registered in 2008 with 20 groups as its members. The main objective of the $\mathrm{CBO}$ was to ensure production of enough milk by its members in a bid to reduce their poverty. Activities of the $\mathrm{CBO}$ were Artificial Insemination (AI) of cows, capacity building in the domain of husbandry practices, merry-go-round, and visits to each other's farms by members. When asked how the group intended to improve the lives of its members, one leader said... "For a community to come up, people must be educated... most people here are farmers...they need good roads to transport their produce..., we need enough drugs and awareness..."

The CBO started as a self-help group by operating a bull service scheme. It joined another group that was carrying out similar activities. One NGO, World Sires donated an Artificial Insemination (AI) kit in 2003 worth Kshs 300,000 (US\$ 3,000). The leader said further...

"The AI service covers all dairy breeds: Friesians, Ayrshire and Guernsey... here people prefer Ayrshires and Friesians.We were trained by the Ministry of Livestock and Fisheries. The Ministry of Agriculture also trained us on crops and how to fertilize them using farm yard manure. We were also sponsored by Brookside Company which deals in milk and other dairy products to attend one of their shows. As a $\mathrm{CBO}$, we elect our officials every 3 years, but if one fails to perform, we remove and replace him/her".

The CBO had a management committee of 13 members (7 men and 6 women) which met fortnightly. Asked what the achievements of the group were, the chairperson commented...

"AI service is now going beyond the group...before we begun, we didn't have improved dairy cattle...now we have them...some members get an income of Kshs 7,000-8,000 (US\$ 70-80) a month...problems of transport have been reduced...we now have a motorbike... we still have a problem of getting liquid nitrogen from towns... another problem is that farmers are not enlightened in livestock keeping...we need to involve them in seminars to create their awareness..."

\section{Businda Village Development Committee}

This group was based in Busia district (now, county) and was formed in 2003 and had nearly 150 members at the time of data collection. The groups' main objective was to help its members improve their education, health and farming. The group implemented the following activities; improvement of water supply through digging of two shallow wells, distribution of mosquito nets to households under the Bamako health, training of primary health care and traditional birth attendants, establishment of early childhood development units to promote education, provision of water pumps for agriculture, development of a poultry project, and providing assistance to orphans to keep goats as an income generating activity.

The group was initiated by outside development partners through the Department of Gender and Social Development (DGSD) and by the chief of the area who identified the project site, mobilized its residents and organized a 12-day training session for them. Additional training was held for leaders. A grant of Kshs 500,000 (US $\$ 5,000$ ) was given to the group in 2004 for agriculture, education and health projects and another Kshs 400,000 (US \$ 4,000) for goats and cereal projects. One requirement for the grants was that members of the community had to raise 30 per cent of the value of the grants which they did in 
the form of labour and materials. The agriculture project required them, among other things, to bulk seeds for their members and the larger community. Each of the projects-water, agriculture, orphans, health and education - had its Project Management Committee (PMC). Members of the community were required to register in the projects. At the time of data collection, 71 households had registered in the water project, 64 in agriculture, 62 in orphans, 58 in health and 50 in education. They registered by paying a joining fee of Kshs 100 (US\$ 1). The PMCs worked under the larger Village Development Committee which was comprised of 30 members (16 men and 14 women).

When asked about the achievements of the VDC, its chairman said.... "We have learnt farming... we have learnt to control diseases...children go to school...sixteen (16) children are attending secondary school...we sell cereals...we have given goats to some members... we have leant to keep poultry and other livestock..."

Whereas the VDC was given hefty assistance at its start, no further assistance had been given up to the time of data collection in 2013. One of its leaders said... "Now the group has no cash... it is bankrupt...".

\section{District Social Development Committee (DSDC), Kakamega County}

This comprised of representatives of self-help groups from all over the district (now, county). Like other DSDCs in other districts of the country, the committee was initiated and supported by the DGSD with the mandate of coordinating activities of self-help groups, recommending them for the department's grants and monitoring their use. The DSDC had 15 members and was part of a hierarchy of similar committees at the sub-district (now, sub-county) and location (now, ward) levels. The membership was inclusive and comprised of not only representatives of self-help groups but also those of the youth, older persons, faith based organizations and Maendeleo ya Wanawake (MYW) (Progress of Women) organization.

The leaders of the committee saw the problems of the district as comprising of low income and associated poor purchasing power, unentrepreneurial attitudes of people, and fear of credit. One of the leaders of the committee said "...Our interest is to uplift the standard of living of the community..."

The committee was provided with office space by the DGSD, the SDO was secretary to its meetings, and all logistics were done by the department including provision of transport. The Committee obtained support from other departments of the government such as those of Cooperative Development and Agriculture when it was training leaders and members of self-help groups. Although NGOs were represented in the DCDC, they did not support it financially. All members of the DCDC worked as volunteers when training and undertaking other activities for the committee. One leader of the DCDC said... "We recommend groups for assistance and monitor their use of the assistance..."

About their achievements, the leader said...

"Disbursement of grants has improved... there is better use of the grants owing to training we give to committees of self-help groups.... We have a large number of applications for the DGSD grants. The grants when disbursed through this committee have more effect...As a committee, we were thinking of converting the grants into a revolving loan fund... If people are empowered, they could fund their own schools and other facilities...Training is key before giving a grant...Community can also start a fund, make contributions and government tops them up".

It is clear from these case studies, that some of them such as Businda were formed on the initiative of outsiders such as the DGSD staff, while others such as Mosocho were formed on the initiative of the community. Similarly, some were much older, for example Businda, while others such as Mosocho and Kabarnet Youth Group were relatively new at the time of data collection. Equally while some of the case study groups such as Kabarnet were concerned with the welfare of their members, others such as Mosocho were concerned with development activities. Likewise, while some of the case study groups such as Businda depended on financial support from development partners, others such as Mosocho made efforts to raise their own resources to supplement those that were provided by partners.

\section{Conclusions and Recommendations}

In this study we have confirmed the importance of self-help groups in development and welfare work. In the past and at present, self-help groups have built or improved schools, health facilities, cattle dips, water sources and other infrastructures such as feeder roads, footpaths and bridges. In farming, the groups have been involved in soil conservation and in crop and livestock keeping and trading activities. The groups have also been involved in table banking, revolving loan schemes and in small scale business activities. In welfare matters, the groups have brought together persons such as PWDs and those infected and affected with HIV and AIDs and enabled them to work together to meet their needs as well as access sources of help. On the basis of these findings, there is potential that the contributions of the self-help groups to the development and welfare of their members and communities could be strengthened in the following ways.

\section{Need to Pay Attention to Individual Members of the Self-help Groups}

The conceptions of community development that were provided by Biddle and Biddle (1965), the United Nations' 
(1963) and other parties emphasized work with groups and whole communities and collective benefits from such efforts. However, this study of self-help groups and others we completed earlier (Chitere, 1988 and 2004) bring into sharp focus the role of the individual members of groups in their development and welfare activities. There are situations where a group collectively carries out a project such as poultry keeping by locating it at a site agreed upon by the members who jointly operate the project and share its benefits and losses. In other situations, the group carries out the collective project at the agreed site but also allows its members to replicate it at their preferred sites, e.g., in their homes. In certain situations, the group supports its individual members to carry out the project at their preferred individual sites. These optional arrangements are found in nearly all self-help group projects including, dairy and fish farming, bee keeping, table banking and access and use of credit. Thus while the conception of community development emphasizes the role of collective initiatives, the self-help groups also need to pay equal attention to individual members and their unique needs.

\section{Membership Contributions}

Whereas members made monetary, material and other contributions to their groups, the contributions were low presumably owing to widespread poverty of their communities and households. However, if self-reliance of the groups were to be achieved, these local contributions would need to be substantially increased.

Financial Support of the Groups by the Agencies

Whereas the DGSD had supported nearly half of the groups, the amounts it gave as grants were very small. Other agencies' grants were somewhat larger but benefitted only a few groups. Except in the case of Businda VDC, there was no indication that the grants given were matched with local contributions. The grants were also not assured. Consequently, there was need for the grants to be matched by local contributions in a manner that would enable the groups to rely on their own resources in future.

\section{Technical Support of the Groups}

Community development being an education process, calls for training and other forms of education to help in building capacity of the groups. The training and education were, however, accessed by less than half of the groups. Thus, there is need for enhancing access of the groups to such capacity building opportunities in the future.

\section{Maturation of the Groups}

Brager and Specht (1973) categorized groups into primary, socialization, organization- development and Institutional Relations Organizations (IROs). Primary and socialization groups were concerned largely with meeting emotional needs of their members; development-organization types were somewhat development oriented while IROs were mature and development oriented. Brager and Specht expressed the view that a community worker needed to work with the IROs and while doing so also assist the other three types of groups, where possible, to re-orient themselves and mature to the status of IROs.

From the findings of the present study, there was no indication that the DGSD had categorized the groups on a similar basis and that it was working more with the mature and task oriented IROs. The department appeared to treat the groups as if they were similar and at the same level, and hence did not help those at the lower levels concerned with emotional needs to move and mature as IROs or as cooperatives. Such an approach will be needed in future.

\section{Need for a Detailed Study}

This study was exploratory. Whereas we presented data on characteristics of individual members of the self-help groups, they were not the focus of this study. It is, however, likely that some of the characteristics could explain the level of performance of the self-help groups. A detailed study of the characteristics and their influence on performance of the groups will be needed in future.

There is also a need, resources permitting, for a detailed study of the self-help groups' movement in Kenya with a view to establishing its real impact on development and welfare of its members and the Kenyan society at large. Such a study would also help develop an intervention strategy that could strengthen the movement and enhance its contribution to the country's development and welfare efforts. 


\section{Annex 1: Self Help Groups and Committees}

\begin{tabular}{|c|c|c|c|}
\hline S/No. & District (now, County) & Name of Self-help group/Committee & Type \\
\hline 1. & Kakamega & District Social Development Committee & District Committee \\
\hline 2. & Kakamega & District Social Protection Committee & District Committee \\
\hline 3. & Kakamega & Karim Women Group & Unit group \\
\hline 4. & Kakamega & Tresa Ofavilla Self-Help group & Unit group \\
\hline 5. & Busia & Businda Village Development Committee & Village Committee \\
\hline 6. & Busia & Singi Sustainable Investment & $\mathrm{CBO}$ \\
\hline 7. & Kisii & Umoja Disabled Self-Help Group & Unit group \\
\hline 8. & Kisii & Mosocho Livestock self-help group & $\mathrm{CBO}$ \\
\hline 9. & Baringo & Kabarnet Physically Challenged Youth Group & Unit group \\
\hline 10. & Baringo & Community Integrated Development Project & Village committee \\
\hline 11. & Narok & Narok Disabled Integrated Development Project & Unit group \\
\hline 12. & Narok & Nairasirasa Nkolia Women Group & Unit group \\
\hline 13. & Narok & Enaitoti Biashara & $\mathrm{CBO}$ \\
\hline 14. & Mombasa & Majengo Muslim Women Group & Unit group \\
\hline 15. & Mombasa & Kenya Muslim Youth Alliance & $\mathrm{CBO}$ \\
\hline 16. & Mombasa & Siri Ya Urembo Women Group & Unit Group \\
\hline 17. & Mombasa & Walea Orphans and Vulnerable Children Support Centre & Unit group \\
\hline 18. & Embu & Juhudi manpower Support Women Group & Unit group \\
\hline 19. & Embu & Tumaini Disabled Self-Help Group & Unit group \\
\hline 20. & Embu & Maisha Women Group & Unit group \\
\hline 21. & Garissa & Upendo Wetu Community Initiative & Unit group \\
\hline 22. & Garissa & Wanag Yale Self-help Group & Unit group \\
\hline 23. & Garissa & Hidig Environmental & Unit group \\
\hline
\end{tabular}

\section{REFERENCES}

Askwith, T. 1960. Progress through self-help: Principles and practice in community development. Nairobi: Eagle Press

Brager, G. and Specht, H., 1973. Community organizing. New York: Columbia University Press

Chitere, P.O. and Ngundo, V.M., 2015. Devolution as a means for self-governance: Its potential for poverty reduction in Kenya. In: International Journal of Social Work and Human Services Practice, Vol. 3 No.1

Chitere, P.O. 2012. The community development movement in Africa during the colonial period (1945-1963) with emphasis on its practice in Kenya. In: J. Mangut and T. Wuam, eds., Colonialism and the transition to modernity in Africa. Ibadan: Joseph Mangut and Terhemba Wuam publishers

Chitere, P.O. 2009. Neighbourhood associations and governance in Nairobi: Their performance and prospects. In: Hekima: Journal of the Humanities and Social Sciences, Vol. IV, No. 1

Chitere, P.O. 1994. Community development: Its theoretical conceptions and practice in Africa. Nairobi: Gideon S. Press

Chitere, P.O. 1988. Women's self-help movement in Kenya: A historical perspective, 1940-1980. In: TransAfrican Journal of History, Vol. 17

Hearsman, K. 1966. Women and community development in Kenya and Uganda. In: Community Development Journal, No.4

Jackson, I.C. 1956. Advances in Africa: A study of community development in Nigeria. London: Oxford University Press

Kariuki, J, 2016. Effectiveness of the Constituency Development Fund as a tool for community development in Kenya, Ph.D. Thesis, University of Nairobi

Kinyanjui, M.N. 2015. Vyama: Institutions of hope: Ordinary people's market coordination and society organization alternatives. Oakville: Nsemia Inc. Publishers

Kolb, J. 1968. Emerging rural communities. Madson: The University of Wisconsin Press

Littell, D.W. 1980. The self-help approach. In: Christenson, J.A. and Robinson, J.W., Jr., Community development in America. Ames: Iowa State University press

Lewa, R.M. 2002. Capacity building programmes among women groups in Mombasa district, Kenya, M.A. Project paper, Department of Sociology and Social Work, University of Nairobi

Mbithi, P.M. and Rasmusson R. 1977. Self-help and self-reliance: The case of Harambee. Uppsala: The Scandinavian Institute of African Studies 
Monsted, M. 1978. Women groups in rural Kenya and their role in development, Centre for Development, Research paper, Copenhagen

Republic of Kenya. 2015. Self-help association's bill. Nairobi: Government Printer

Republic of Kenya Vision 2030. Nairobi: Government Printer

Republic of Kenya, The Constitution, 2010. Nairobi: Government Printer

Republic of Kenya, 2012. District Social Development, a report of the workshop held at the Kenya Institute of Curriculum Development, Nairobi, March.

Republic of Kenya, 1965. Sessional paper No. 10, Ministry of
National Planning and Development, Nairobi.

Republic of Kenya, 1964-1969. Development plan, Ministry of National Planning and development, Nairobi

United Nations, 1959. cited in Littrell op. cit.

United Nations.1963. Community development and national development, a Report by an Ad hoc Group of Experts appointed by the Secretary General, New York

World Health Organization/UNICEF 1987. The Bamako Initiative of Primary health care in Sub-Saharan Africa, Bamako, Mali

Wileden, A.F. 1970. Community development. New York: The Bedmister Press 